\title{
Diglossia versus Register: Discursive Classifications of Two Sinhala varieties
}

\author{
CALA ZUBAIR \\ University of Buffalo
}

\section{Introduction}

Though Sinhala is the native language of the majority Sri Lankan Sinhalese population, it consists of two contrastively defined varieties commonly referred to as 'Colloquial' and 'Formal' Sinhala. In categorizing spoken Sinhala into a 'formal' and 'colloquial' variety, past research (Gair 1968; DeSilva 1974; Paolillo 1997) draws primarily on Ferguson's $(1959,1991)$ notion of diglossia where two related languages are lexically and grammatically distinct and prescriptively used in different social domains. Formal Sinhala includes elaborate nominal declensions and verbal paradigms and is the primary medium of bureaucratic and state-funded educational establishments. Colloquial Sinhala is the informal variety used outside of institutional settings with simplified tense, pronominal systems and a distinct lexicon. Problematizing diglossia theory's reliance on axiomatic grammatical categories and discrete formal and informal social environments as well as prestige values, I utilize Agha's (2007) recent reworking of register theory (cf. Biber \& Finnegan 1994; Biber 1995; Milroy 2001) to move beyond diglossia's dichotomous, top down classification system, at the expense of more dynamic approaches to language variety classification. Agha's enregisterment model incorporates the sociohistorical contexts through which diglossic formations emerge, particularly prioritizing the role of discourse in creating, maintaining, or challenging diglossic systems.

The discourse I focus on in this study comes from interviews and ethnographic work with Sri Lankan university youth. While diglossia theory proves insufficient in depicting the way these youth mix 'formal' and 'colloquial' morphosyntactic features in the same social setting, Agha's register approach to Sinhala optimally accounts for the specific dialogic effects speakers attach to linguistic features, suggesting such interdiscursive meaning combined with sociohistorical backgrounds of the varieties explains the registers' composite recognition as divergent. 
My work specifically builds on Agha (2007) in understanding diglossia maintenance and change through instances of specific discursive interactions, whereas previous enregisterment studies have relied on evidence from widely available pubic discourses. Also, I build on Sinhala language studies. While much descriptive linguistic research on these varieties exists, few studies have made use of natural speech samples and no strictly sociolinguistic study has considered the discursive construction of each variety.

\section{$1 \quad$ Diglossia Revisited}

Ferguson introduced the term diglossia, borrowed from the French term 'diglossie' (Marsais 1930), meaning 'bilingualism,' to describe two superposed but functionally differentiated 'high' and 'low' prestige varieties. Since Ferguson's initial 1959 study of Arabic, Greek, German, and Haitan Creole diglossia scholars in a diverse range of fields (linguistics, anthropology, sociology, and education) have adopted this concept to study language variation (Bell 1976), language planning and maintenance (Fishman and Das Gupta 1986), language standardization and dialectology (Fasold 1984; Yaeger-Dror 1988), code switching, bilingualism, and language contact (Fishman 1967).

Table (1) below shows the criteria developed in Ferguson's (1959) study to label 'High' $(\mathrm{H})$ versus 'Low' $(\mathrm{L})$ varieties. Notably, functional differentiation of $\mathrm{H}$ and $\mathrm{L}$ varieties is considered to be stable, reinforced through standardization of the $\mathrm{H}$ variety in grammars, dictionaries, and canonical texts. In addition, $\mathrm{H}$ varieties closely resemble older, written forms of a language as found in literary works. Because of such a resemblance, $\mathrm{H}$ varieties are typically more grammatically complex than $\mathrm{L}$ varieties (as indicated in the table below) and spoken in what Ferguson calls 'formal' settings, such as educational, state, and institutional establishments. L varieties are spoken 'informally' among family and friends and are acquired from parents. $H$ varieties are learned in school and are collectively viewed as a more educated, prestigious, or correct way of speaking. Thus, $\mathrm{H}$ varieties are the prestigious variety and L varieties and usually not valued by the community, considered 'bad' or 'uneducated' language (Schiffman 1978).

(1) Table 1: Ferguson's Diglossia Rubric

\begin{tabular}{|l|l|l|}
\hline & High Variety & Low Variety \\
\hline $\begin{array}{l}\text { Functional } \\
\text { differentiation across social } \\
\text { spheres }\end{array}$ & $\begin{array}{l}\text { Spoken in formal set- } \\
\text { tings: educational, } \\
\text { state, institutional, } \\
\text { certain types of media }\end{array}$ & $\begin{array}{l}\text { Spoken informally: } \\
\text { among friends, } \\
\text { family, outside of } \\
\text { institutions }\end{array}$ \\
\hline Prestige & 'High' prestige value & 'Low' prestige value \\
\hline
\end{tabular}


Diglossia Versus Register: Sinhala

\begin{tabular}{|l|l|l|}
\hline Literary Heritage & $\begin{array}{l}\text { The language of a large } \\
\text { body of classical litera- } \\
\text { ture including } \\
\text { canonical religious } \\
\text { texts, ancient poetry, } \\
\text { public speeches }\end{array}$ & $\begin{array}{l}\text { No written records or } \\
\text { literary cannon } \\
\text { supporting this varie- } \\
\text { ty; much changed } \\
\text { from written language }\end{array}$ \\
\hline Acquisition & $\begin{array}{l}\text { At school through } \\
\text { education }\end{array}$ & $\begin{array}{l}\text { Learned first at home } \\
\text { from parents }\end{array}$ \\
\hline $\begin{array}{l}\text { Stability through Standardi- } \\
\text { zation }\end{array}$ & $\begin{array}{l}\text { Standardized through } \\
\text { grammars, dictionaries, } \\
\text { canonical texts }\end{array}$ & Rarely standardized \\
\hline $\begin{array}{l}\text { Structure (grammar, lexicon, } \\
\text { phonology) }\end{array}$ & $\begin{array}{l}\text { More complex gram- } \\
\text { mar; different lexicon } \\
\text { (possible overlap); } \\
\text { shared morpho- } \\
\text { phonemics or } \\
\text { comprising a Superset }\end{array}$ & $\begin{array}{l}\text { Less complex } \\
\text { grammar, different } \\
\text { lexicon (possible } \\
\text { overlap), shared mor- } \\
\text { phophonemics or sub- } \\
\text { set of H variety }\end{array}$ \\
\hline
\end{tabular}

Now revisiting some of diglossia's classification principles, I will focus on the issues of functional differentiated language use among 'formal' versus 'informal' social settings, prestige value of $\mathrm{H}$ and $\mathrm{L}$ varieties, and the limits of morphosyntactic repertoire categorizations. First, diglossia theory's prescriptive use of dichotomous formal/informal social settings, where formal settings predict the use of an $\mathrm{H}$ variety (Formal Sinhala) and informal settings predict the use of an $\mathrm{L}$ variety (Colloquial Sinhala) cannot account for the code mixing that speakers in my study exhibited. As Wilce (2010) notes, code mixing under Fergusons' model may either be interpreted as impossible, or unlikely due to the fact that codes are designated for fixed speech environments where violations would be so negatively valued, they would never, or rarely occur.

Moreover, approaching language with this initial taxonomic view of speech setting, formal versus informal, cannot explains differences in social meaning of the varieties cross-generationally. In other words, Ferguson's prestige scale conflates prestige with functional differentiation of varieties (including use across different settings), where institutionalized language is automatically labeled as more prestigious, overlooking speaker demographics, instances of covert prestige, and counter-valorizations of varieties. For certain groups of speakers, such as the youth I interviewed in this project, speech will indicate that the L variety, or Colloquial Sinhala, is in fact prestigious, valorized by youth who denigrate the formal, 'High' variety. 
As the topics of social setting and prestige scales have been defined, by Ferguson (1959) and in subsequent studies, they also reflect a narrow methodological labeling that overlooks the crucial sociohistorical narratives and ideologies surrounding 'varieties' or 'registers.' Particularly, researchers have failed to treat what Agha (2007) calls 'reflexive' semiotic processes, processes that depict how linguistic units are valued, and which create and reinforce boundaries between use of H and L varieties (cf. Silverstein 1996; Agha 2002; Irvine and Gal 2000; Haeri 2003). Within the Sinhala literature especially the formal/informal division led researchers to identify and name two varieties of Sinhala as 'Formal' and 'Colloquial.' These quantifier free names depict a stereotypical assumption that the varieties are universally used in either a formal or colloquial setting. Without giving details on what counts as formal or colloquial, who uses which variety and when, the names also assume social settings fit into neat compartmentalized categories and that these categories apply across a range of locales. The names reify a false dichotomy for researchers as well as speakers. Without substitute names, for the present, I will continue to call each variety formal and colloquial, though the names of Sinhala varieties will be something I consider for future research.

\section{The Sinhala Language: Morphology, Syntax, Lexicon}

In addition, past Sinhala studies (DeSilva 1974, 1979; Gair 1968, 1998; Fairbanks et al 1986; Paollilo 1992, 1997) detail in abundance how the Colloquial variety is distinct from Formal Sinhala in several morphosyntactic ways (Table 2). Colloquial Sinhala nouns have a less complex declension, fewer cases, differences in semantic and syntax of cases, lack of subject/verb agreement, and simplified tense, mood, and voice when compared with Formal Sinhala. Formal Sinhala maintains subject/verb agreement in person, number, and gender and has complex nominal declensions reminiscent of the written, literary variety. Formal Sinhala also has a different lexicon than Colloquial for prepositions, conjunctions, pronouns, and deictics (Gair 1968). Additionally, because Formal Sinhala has evolved from an older, literary tradition which is closely related to the ancient Indo-Aryan languages of Sanskrit and Pali, many of its lexical items are not used in Colloquial Sinhala or are used in a changed form. 
(2) Table 2: Colloquial and Formal Sinhala

\begin{tabular}{|l|l|l|}
\hline & Colloquial Sinhala & Formal Sinhala \\
\hline Nouns: Declension & SG/PL & $\begin{array}{l}\text { SG/PL } \\
\text { MASC/FEM } \\
\text { ANIM/INANIMATE }\end{array}$ \\
\hline Case & $\begin{array}{l}\text { NOM, ACC, DAT, } \\
\text { GEN, INSTR, LOC }\end{array}$ & + ABL, VOC, AUX \\
\hline Semantics of case & $\begin{array}{l}\text { 1) LOC: place } \\
\text { 2) ACC: patient subjects }\end{array}$ & $\begin{array}{l}\text { 1) LOC: time and place } \\
\text { 2) INSTR: patient } \\
\text { subjects }\end{array}$ \\
\hline $\begin{array}{l}\text { Syntax of Case } \\
\text { Argument realization) }\end{array}$ & INSTR: object/oblique & $\begin{array}{l}\text { INSTR: } \\
\text { subject/object/oblique }\end{array}$ \\
\hline Verbs: SV AGR & NPRES, PRES & + FUT, PER, IMPER \\
\hline Tense & IND, IMP, OPT & +COND \\
\hline Mood & Active & Active/Passive \\
\hline Voice & SOV & unfixed \\
\hline Word Order & &
\end{tabular}

While these structural differences are noteworthy, such a 'repertoire-based' perspective, a categorization of grammatical lexical, phonetic, and other structural ways the two language varieties differ (Agha 2007: 148), remains incomplete. These analyses fail to consider sociohistorical evidence, natural speech data, or the discursive construction of each variety. Without an initial sociohistorical study, they cannot explain how widespread functional differentiation contributed to the evolution of structural divergence or how such structures became associated with social practices at all. In answer to this, I give a brief introduction of the macro-social narratives identified with each variety in Section 3, followed by an analysis of natural speech samples in Section 4.

\section{Sociopolitics: Cultural Preservation Versus Modernism}

The story of the Formal and Colloquial varieties begins with past struggles of nationalism versus current moves for the state's upward economic mobility. Ideologically, I characterize this as cultural preservation through Formal Sinhala versus modernism as attached to Colloquial Sinhala.

Formal Sinhala became an essential part of nationalist identity in the decades surrounding the country's postcolonial independence (1930's-1940's). Sinhala 
nationalists made policies targeting students as a vital demographic for cultural preservation in the face of modernism; and Formal Sinhala the vehicle of purism through which students could regain this idealized, pre-colonial way of life. Born from efforts to gain majority rule, such policies promoted discourses of ethnic nationalism, valorizing Formal Sinhala through a series of 'Sinhala -only' campaigns. These campaigns promoted Formal Sinhala as the premier language for all aspects of the newly formed, democratized and bureaucratized state. Throughout the 1940s, voices like future prime minister J.R. Jayawardene called for change in the official government language rallying before the State Council for Sinhala to replace British, Colonial English as the primary medium of government and state institutions. In 1956, Congressman Bandarnaike won the presidency on the 'Sinhala-only' platform, utilizing language policy as a way to cross cut class lines and unite the people with visions of a unified Sinhalese state (DeVotta 2003). Promising Formal Sinhala language instruction would lead to recovery of a lost culture and strengthen the bonds of statehood, the 1960s parliament began to fund schools where Formal Sinhala was the primary medium of instruction (Kearney 1967; Sharma 1988). These schools, unlike pre-existing, British- founded private schools, were made publically accessible to all demographic groups, and currently comprise the majority of primary and secondary educational institutions on the island. Thus, with increased government job opportunities and education institutions backing this variety, there has been a rise in country wide proficiency in Formal Sinhala and institutional proliferation of ideological associations between this 'pure' variety and cultural preservation.

However, while Sinhalese nationalists have repeatedly valorized Formal Sinhala, proclaiming student education in this variety essential (Dharmadasa 1993; DeVotta 2003), the Colloquial Sinhala variety has continued to make up a fundamental part of everyday language including use in casual conversations, social encounters outside of institutional settings, use on the internet (facebook pages), in media (i.e. TV dramas, pop radio shows), and particularly as a fundamental part of present day youth identity. Particularly, the state has allotted funds in the last 10 years to supplement Formal Sinhala medium classrooms with English language instruction in an effort to become more competitive in the global market and lend support to the country's growing economic crisis. Thus, while more youth are gaining skills in English, this is at the expense of Formal Sinhala. In many ways the new cosmopolitan, youth student is associated not only with English, but with Colloquial Sinhala usage where a lack of Formal Sinhala education has robbed her of knowing any better.

Moreover, youth are using and engaging in Colloquial Sinhala in an increasing number of new media. With the spread of the internet, for example, and need for efficient transliterations of Sinhala text, youth have relied on the colloquial variety, adding inventive slang forms to its repertoire. Newer, youth-oriented TV and radio stations are competing with older, more established news stations and 


\section{Diglossia Versus Register: Sinhala}

news shows, broadcasting music videos and talk shows with youth speaking Colloquial Sinhala.

Such usages of Colloquial Sinhala are a hot topic for conservative nationalists who discuss youth proficiency in Formal Sinhala on radio and televised debates, suggesting how the government can continue to uphold this endangered, 'pure' language. Additionally, cultural sections of Formal Sinhala newspapers often host commentary with Sinhala scholars commenting on the way these usages 'pollute' the Formal Sinhala language that has survived seemingly unchanged for so many centuries. The colloquial language is charged with leading to the endangerment and extinction of the true Sinhala language and the heritage it carries with it (Dharmadasa 1993).

\section{Nationalist Parodies: 'Formal' Usages in 'Colloquial' Encounters}

Moving on to some examples of how you use Formal and Colloquial Sinhala, the following data comes from youth speakers in informal, conversational interactions. For the present study, I am tentatively labeling use of 'formal' language in bolded font, where surrounding italic segments constitute 'colloquial' language (as per past Sinhala morphosyntactic studies discussed in Section 2).

(3) Example 1

(a) Jayantha

$\begin{array}{lllll}\text { Mang eyaaTə } & \text { MahindaTo 'hi' } & \text { kiyanna } & \text { kiyuwa. } \\ \text { 1SG. 3SG. } & \text { Mahinda. hi } & \text { say. } & \text { say. } \\ \text { NOM DAT } & \text { DAT } & \text { IMP } & \text { PST } \\ \text { 'Tell him to say 'hi' to Mahinda for me.' } & \end{array}$

(b) Chathura (voicing

Kavan)

$$
\begin{aligned}
& \text { Ou eyaa kiyznəwa ehe iddi, } \\
& \text { yeah 3SG.NOM say.NPT there stay.PST } \\
& \text { 'Yeah, he says there, }
\end{aligned}
$$

(c) Chathura

(voicing

Kavan)

$\begin{array}{lll}\text { "Ayubowan } & \text { gauruwuniya } & \text { puthrəyaa." } \\ \text { greetings } & \begin{array}{l}\text { honorable } \\ \text { "Greetings honorable, son.", }\end{array}\end{array}$

(d) Jayantha

(voicing the

President

$\begin{array}{cll}\text { "Bohoma istuthi } & \text { MAGE } & \text { puthrəyaa." } \\ \text { many } & \text { thanks, } & \text { 1SG.GEN } \\ \text { " "Many thanks, MY son.", } & \end{array}$


Here Jayantha and Chathura engage in a casual conversation, constructing a dia$\log$ between their friend Kavan, newly appointed to a government post, and the president of Sri Lanka, Mahinda Rajapaske. The speakers use the realm of the state as the common component hypothetically linking the two characters. As Chathura plays the voice of Kavan, he parodies his friend's misuse of the formal variety. Meaning to greet the 'President' with a formal word equivalent to English sir, 'Kavan' instead calls the 'President' puthryyaa 'son' in line (3c) (an unlikely mistake since the 'colloquial' word for son is puthaa, a shortened version where the final morphology is dropped). Jayantha responds in line (3d), with the voice of the 'President' who points out 'Kavan's' mistake by calling 'Kavan' puthryyaa 'son.' With emphasis on the word mage 'my', the 'President' not only draws attention to 'Kavan's' misuse of a formal term, but uses a colloquial pronoun that contrasts with the surrounding formal speech, thus suggesting that Kavan requires a colloquial insert to understand his mistake.

Where diglossia research predicts resolute 'colloquial' speech, here youth are violating theoretical expectations by shifting into 'formal' features in an informal setting. Such code mixing seems to be directly related to how each variety is discursively constructed and representative of different ideologies. In other words, these speakers use the two varieties to achieve specific dialogic affects. They construct Formal Sinhala dialog in the midst of a Colloquial Sinhala conversation to parody the way a youth speaker uses the variety, which both detaches it from a youth character type and connects it to older, authoritative politician.

In Example 2, Priya, Sharmilla, and Buddhika discuss a friend who's father was a diplomat and knew the former Prime Minister, whom they think attended their friend's sister's wedding.

(4) Example 2

(a) Priya

$\begin{array}{lllll}\text { Oyaa eyaage thatha diplomat kennek dannəwa-də? } \\ \text { 2SG. } & \text { 3SG. father diplomat person } & \text { know. } \\ \text { NOM GEN } & & & & \text { NPT-Q }\end{array}$

'You know his dad was a diplomat?'

(b) Priya

$\begin{array}{lll}\text { Eyaa } & \text { Ranilwo } & \text { dannəwa. } \\ \text { 3SG.NOM } & \text { Ranil.ACC } & \text { know.NPT } \\ \text { 'He knows Ranil.' } & \end{array}$




\section{Diglossia Versus Register: Sinhala}

(c) Shar-

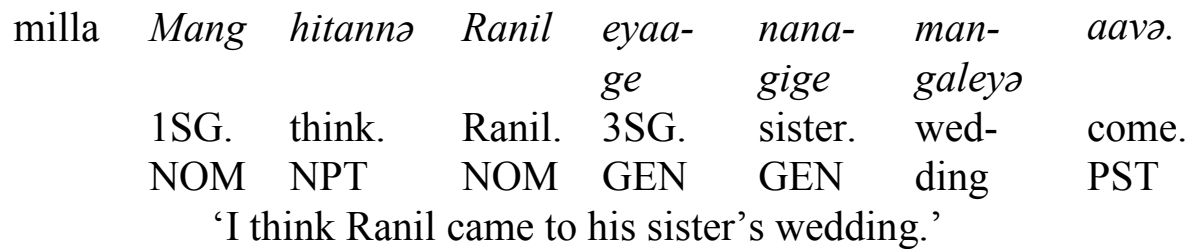

(d) Buddhika

$\begin{array}{llllll}\text { Ou, macho door } & \text { langa } & \text { hitəgənnə } & \text { hitəyə. } \\ \text { yeah dude door near } & \text { stand.NPT } & \text { stay. } \\ & & & & \text {.PART } & \text { PST }\end{array}$

'Yeah, dude was standing near the door.'

(e) Buddhika

(voicing

Shehan)

$\begin{array}{lll}\text { "Karunawen } & \text { aathuləTə ennə, } & \text { sir." } \\ \text { respectfully } & \text { inside.DAT come.NPT } & \text { sir } \\ \text { " "Respectfully come inside, sir.", } & \end{array}$

(f) Buddhika

(voicing

"Buffet ekaTa meheng innə."

Shehan) buffet DEF.DAT way come.NPT

" "Come this way for the buffet.",

(g) Buddhika

(voicing
"Ah tharunayan nithərəmə ba- laaporoththuwa
، "Ah, the youth continuously...

R.W.) youth continue expectation

(h) Buddhika

(voicing

...vinaashə karənəwa naeae.

R.W.)

destroy do.NPT NEG

...cease to disappoint.",

In lines (4e-h), Buddhika plays the voice of both his friend and the former Prime Minister of Sri Lanka, Ranil Wickremasinghe (R.W.), creating a scenario where his friend welcomes Mr. Wickremasinghe to a wedding. Similar to Example 1, here a youth speaker's Formal Sinhala is being parodied where lines (4e-f) represent the voice of the friend and fellow classmate, Shehan. In line (4e), we see formal lexical items karunawen aathulaTo 'respectfully inside' being paired with a colloquial verb ennə 'come.' In line (4f), Shehan switches completely to Colloquial Sinhala, the humorous crux of this line resting on the word buffet, which 


\section{Cala Zubair}

stands out amongst formal speech both because of the English usage, and Shehan's social faux paux of openly admitting that food is the way to the wedding guest's heart. Since in lines (4g-h) 'Mr. Wickremasinghe' expresses pleasure in Shehan's welcome, however, Shehan is excused for his 'rough' colloquial language that did not offend the 'Prime Minister' as evidenced by his reassurance using the expected Formal Sinhala in lines (4g-h).

Again, youth discourse is characterizing Formal Sinhala as the language of politics, characterizing a well-known political figure as the stereotypical speaker whose proper use of Formal Sinhala indicates this variety is not the language of a younger speaker, whose usage fails in comparison.

Looking briefly at one last example, we see that Formal Sinhala is not always used as the voice of politicians but can also be more generally associated with older, authoritative speakers:

\section{(5) Example 3}

(a) Manjula

$$
\begin{array}{llll}
\text { Nah, machang. } & \text { 'Abey' } & \begin{array}{l}
\text { nithərəmə } \\
\text { kiuwa }
\end{array} \\
\text { No dude } & \text { Mr. Abeygunawardana } & \begin{array}{l}
\text { say.PST. } \\
\text { PRG }
\end{array}
\end{array}
$$

'No dude. 'Abey' used to say...

(b) Manjula (voicing Mr. A)

$\begin{array}{llllll}\begin{array}{ll}\text { "Mehe enda, mehe } \\ \text { here }\end{array} & \begin{array}{l}\text { enda, } \\ \text { come. }\end{array} & \text { here } & \begin{array}{l}\text { mehe } \\ \text { come. }\end{array} & \text { enda." } \\ & \text { NPT.IMP } & & \text { NPT.IMP } & & \text { come. } \\ & & & & & \text { NPT.I } \\ & & & \text { MP }\end{array}$

..."Come here, come here, come here.",

(c) Kenneth

$\begin{array}{llll}\text { (voicing } & \text { "Aiyoooo, umba poda sir." } \\ \text { Mr. A) } & \text { EMP } & \text { 2.SG.NOM small sir } \\ & \text { "Ooooh, you are a small one, sir.", }\end{array}$

(d) Kenneth

\begin{tabular}{cccc} 
(voicing "Ou, mang & ithing & kallu." \\
himself) & yes & 1.SG.NOM EMP black \\
& \multicolumn{2}{c}{ (literally 'I am black') }
\end{tabular}




\section{Diglossia Versus Register: Sinhala}

(e) Kenneth (voicing

Manjula)

Nah machang. Mr. Abeygunawardana, sir...

no dude Mr. Abeygunawardana sir

'No, dude Mr. Abeygunawardana, sir...

(f) Kenneth

(voicing

nithərəmə "Miina, miina, miina, miina." ki:u:wa,

Manjula)

say.PST. here here here here

PRG come. come. come. come. NPT.IMP NPT.IMP NPT.IMP NPT.IMP ...used to say, “Com'ere, com'ere, com'ere.",

(g) Manjula

$\begin{array}{llllll}\text { Me } & \text { ithing.. } & \text { umbage } & \text { kallu } & \text { ammi. } & \text { Mang- } \\ \text { well } & \text { EMP } & \text { 2.SG. } & \text { black } & \text { mommy } & \text { 1.SG.NOM } \\ & & \text { GEN } & & & \end{array}$

'Well, this thing..your mother was unworthy. I-'

(h) Kenneth

$\begin{array}{llllll}\text { Dhang } & \text { 'mang'? } & \text { Dhang } & \text { 'mang'. } & \text { Hella Basa, } & \text { no? } \\ \text { now } & 1 . S G . & \text { now } & \text { 1.SG. } & \text { 'true' } & \text { no } \\ & \text { NOM } & & \text { NOM } & \text { language } & \end{array}$

'Now you say 'I' (informally)? Now 'I:' (informally). Formal Sinhala, no?' (i.e. What about Formal Sinhala?)

In this example, Kenneth and Manjula are discussing an old school teacher. Manjula begins in line (5a-b) by correcting Kenneth's impersonation, introduces his voicing of the teacher with the Formal Sinhala quotative nithorəmo kiuwa 'used to say' (5a), then using the Formal Sinhala that the teacher would have addressed them with. Kenneth responds in lines (5c-d) by continuing his impersonation, but note he is still using mostly Colloquial Sinhala. Then in line (5e-f), Kenneth turns to mocking Manjula. Using the formal morphology on the verb 'say' in (5f), he repeats Manjula's nithərəmə kiuwa 'used to say' from (5a). Kenneth draws attention to the formal usages through elongated initial and medial vowels (ki:u:wa 'say'). Asserting that Mr. Abeygunawardana would have said miina, miina, miina 'com'ere, com'ere, com'ere,' Kenneth mocks Manjula's voicing of the teacher in Formal Sinhala (mehe enda 'come here') using an elongating vowel [i] to combine the Sinhala for 'come here' so that it becomes mina 'com'ere.' Manjula responds in line $(5 \mathrm{~g})$ with an insult to Kenneth based on his 
low birth not only mentioning his mother, but mirroring Kenneth's use of the pronoun $u m b a$ 'you' in line (5c), which is a slang term used in derogatory social deixis (Tilakaratne 1988). Ignoring the insult, in line (5h), Kenneth instead highlights Manjula's use of the colloquial $1^{\text {st }}$ person pronoun, mang 'I,' asking him why he is no longer speaking Hella Basa.

The use of this term specifically references nationalist language ideology. Hella Basa historically refers to a variety of literary Sinhala from the $13^{\text {th }}$ century A.D. which was resurrected by nationalist discourses in the 1950s to refer to 'the true, heritage language' and is now largely interchangeable with Formal Sinhala (Dharmasada 1993). Kenneth's use of this term connects Manjula's Formal Sinhala to past nationalist discourses at the same time framing Formal Sinhala as the language of an older generation (with nationalist political leanings) to be mocked when used by younger speakers.

As in Example 1 and 2, Example 3 clearly shows that mixing of the two Sinhala registers occurs. Thus, the most straightforward question becomes why? Or, how are linguistic forms associated with readable ideologies? As suggested in Examples 1 and 2, these speakers are borrowing formal speech to parody other speakers using Formal Sinhala, more specifically their peers' shaky confidence in the variety. Distancing themselves from this variety, speakers portray authoritative figures, teachers and politicians as the voice of the formal variety, characters of the older generation who hold positions where they must comfortably use formal language and as such are stereotypically associated with the nationalist rhetoric. In Example 3, we saw that just as youth mock their peers' poor usage of Formal Sinhala, they can also denigrate their peers' proper usage, aligning themselves with the Colloquial variety. Kenneth's parody of Mr. Abeygunawardana, forcefully injecting colloquial speech into his mouth, not only rejects Manjula's correction, but also rejects Formal Sinhala.

These parodies, then, exhibit reflexive processes that indicate Formal Sinhala holds a different prestige value for different social groups. Judging from sociohistorical evidence (Section 3) where Formal Sinhala was widely esteemed in politics, the media, and educational institutions, by favoring Colloquial Sinhala, these youth are reanalyzing ideologies associated with registers of Sinhala. Such a cross-generational counter valorization, expresses the gap between older nationalists who were pushed to learn Formal Sinhala and youth who identify with the Colloquial variety. Contrary to widespread state institutional policies, these examples select Colloquial Sinhala as the prestige variety where use of 'formal' features results in parody or mocking.

\section{Conclusion}

What do these parodies of Formal Sinhala mean for diglossic classifications of Sinhala varieties? Straightforwardly labeling such parodies as either 'formal' or 'colloquial' based on diglossia's clear cut social settings with attributed prestige 


\section{Diglossia Versus Register: Sinhala}

values fails to accurately depict how youth operationalize 'formal' grammatical features as a speech type to charaterize oppositonal personas.

With the loss of social setting as a definitive classifier of $\mathrm{H}$ and $\mathrm{L}$ variety, diglossia's top down categorization of linguistic features is also questionable. Indeed, while labeling features 'formal' and 'colloquial,' I have maintained labeling based on past morphosyntactic studies, but come across speech which is not easily identifiable as formal and colloquial (see also Paolillo 1997). Documenting shared features between the varieties, then, is an important topic for further study which may additionally update diglossia theory. Expecting that some linguistic features are present in both varieties, speakers repeated use of 'formal' phrases in 'colloquial' settings can bi-directionally signal and cause the insertion of Formal Sinhala grammar into the colloquial variety. Such usage reclassifies and blurs the lines of grammatical classification for each variety, even if mixing begins only as limited register representation of certain stereotypical speakers.

By extension, researchers may be more accurate in considering that Formal and Colloquial Sinhala exist along a continuum. Clearly, the way speakers and listeners recognize and discursively assign value to linguistic features indicates the need for a less dichotomous, more dynamic model of classification than diglossia theory presently provides. Attention to sociohistorical ideologies and interactional reflexive language behavior reveals dynamic, emergent meanings which are as equally important as considering social setting and morphosyntactic categorization. Beginning with such a bottom up discursive approach recognizes language ideology as a motivating factor for variety classification where language can be reanalyzed and regrouped cross-generationally and in the name of ethnic or political identity, as is the case when this Formal Sinhala register is employed by this specific set of youth (Agha 2007). Thus, reframing methods of language classification to include discursive interactions speaks to central issues in the study of language variety, especially the traditional 'diglossic' classification of older, written linguistic forms versus newer, colloquialisms (c.f. Egyptian/ Modern Standard Arabic: Haeri 2003; Spanish/ Catalan: Pujolar 2001; Javanese/ Indonesian: Errington 1998).

\section{References}

Agha, A. 2002. Honorific Registers. K. Kataoka and S. Ide (eds). Culture, Interaction, and Language. Tokyo: Hituzisyobo. 21-63.

Agha, A. 2007. Language and Social Relations. Cambridge: Cambridge University Press.

Bell, R. 1976. Sociolinguistics: Goals, Approaches and Problems. New York: St. Martin's. 
Cala Zubair

Biber, D. and E. Finnegan. 1994. Sociolinguistic Perspectives on Register. New York: Oxford University Press.

Biber, D. 1995. Dimensions of register variation. A cross-linguistic comparison. Cambridge: University Press.

DeSilva, M. W. S. 1974. Convergence in diglossia: the Sinhalese sittion. International Journal of Dravidian Linguistics 3.1: 60-91

DeSilva, M.W.S. 1979. Sinhalese and Other Island Languages of South Asia. Tübingen: Gunther Narr Verlag

DeVotta, N. 2003. Ethnolinguistic nationalism and Ethnic Conflict in Sri Lanka. M. Brown \& S. Ganguly (eds.). Fighting Words: Language policy and Ethnic Relations in Asia. Cambridge: BCSIA Studies in International Security.

Dharmadasa, K.N.O. 1993. Language, Religion, and Ethnic Assertiveness. Michigan: University of Michigan Press.

Errington, J. 1998. Shifting Languages: Interaction and Identity in Javanese Indonesia. Cambridge, MA: Cambridge.

Fairbanks, G.H., J.W. Gair and M.W.S. De Silva. 1986. Sinhala Diglossia Revisited, or Diglossia Dies Hard. B. Krishnamurti (ed.). South Asian Languages: Structure, Convergence \& Diglossia, 233-36. Delhi: Motilal Banarsidass.

Fasold, R. 1984. The Sociolinguistics of Society. Oxford: Basil Blackwell. Reviewed by F. Anshen, International Journal of the Sociology of Language, 1986 57:107-11.

Ferguson, C. 1959. Diglossia. Word 15: 325-340.

Ferguson, C. 1991. Diglossia Revisited. Southwest Journal of Linguistics 10(1).

Fishman, J. I967. Bilingualism with and without diglossia; diglossia with and without bilingualism. Journal of Social Issues 23(2):29-38.

Gair, J. W. 1968. Sinhalese Diglossia. B. Lust (ed.). Studies in South Asian Linguistics: Sinhala and Other South Asian Languages. Oxford: Oxford University Press. 213-223. 


\section{Diglossia Versus Register: Sinhala}

Gair, J. W. 1998 (1985). Sinhala Diglossia Revisited, or, Diglossia Dies Hard. B. Lust (ed.). Studies in South Asian Linguistics: Sinhala and Other South Asian Languages. Oxford: Oxford University Press. 224-236.

Haeri, N. 2003. Sacred language, ordinary people: Dilemmas of culture and politics in Egypt. New York: Palgrave Macmillan.

Irvine, J. and S. Gal. 2000. Language Ideology and Linguistic Differentiation. P. V. Kroskirty (ed). Regimes of Language. Santa Fe: School of American Research. 35-84.

Kearney, R. 1967. Communalism and language in the politics of Ceylon. Durham: Duke University Press.

Marsais, W. 1930. La diglossie arabe. L'Enseignement Public 97(12):401-09.

Milroy, L. 2001. Style, register and sociolinguistic analysis. P. Eckert and J. Rickford (eds). Language, context and the relational self: retheorising dialect style in sociolinguistics. Cambridge: Cambridge University Press. 268-278.

Paolillo, J. C. 1992. Functional Articulation in Diglossia: a Case Study of Grammatical and Social Correspondences in Sinhala. Ph.D. dissertation, Stanford University.

Paolillo, J. C. 1997. Sinhala diglossic variation: continuous or discrete? Language in Society, 26.2: 269-96

Pujolar, J. 2001. Gender, Heteroglossia and Power: A Sociolinguistic Study of Youth Culture. Berlin: Mouton de Gruyter.

Schiffman, H. 1978. Diglossia and Purity. C. Maloney (ed.). Language and civilization change in South Asia. NY: E.J. Brill-Leinden. 98-110.

Sharma, K. 1988. Society and polity in modern Sri Lanka. New Delhi: South Asian Publishers.

Silverstein, M. 1996. The Secret Life of Texts. M. Silverstein and G. Urban (eds.). Natural Histories of Discourse. Chicago: University of Chicago Press. 81-105.

Tilakaratne, S. 1988. Social Deixis in Sinhalese: The Pronoun System. KansasWorking Papers in Linguistics 13. 


\section{Cala Zubair}

Wilce, J. 2010. Society, Language, History, and Religion: A Perspective from Linguistic Anthropology. T. Omoniyi and J. Fishman (eds.). The Sociology of Language and Religion. New York: Palgrave.

Yaeger-Dror, M. 1988. The influence of changing group vitality on convergence toward a dominant linguistic norm: An Israeli example. Language and Communication 8:285-305.

Cala Zubair

Department of Linguistics

605 Baldy Hall

University at Buffalo

Buffalo, NY 14260-7022

calazuba@buffalo.edu 